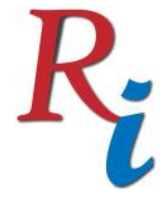

Asia Proceedings of Social Sciences

(APSS)

www.readersinsight.net/APSS

\title{
HEALING THE SiCK IN PORTUGUESE MELAKA FROM 1511-1641
}

\section{Meljev Singh Sidhu}

Centre for Global Archaeological Research (Formerly)

Universiti Sains Malaysia (Formerly)

Malaysia

meljevss@yahoo.com

*Corrosponding author's Email: meljevss@yahoo.com

Peer-review under responsibility of 4th Asia International Multidisciplinary Conference 2020 Scientific Committee

http://connectingasia.org/scientific-committee/

(C) 2020 Published by Readers Insight Publisher,

lat 306 Savoy Residencia, Block 3 F11/1,44000 Islamabad. Pakistan,

editor@readersinsight.net

This is an open access article under the CC BY-NC-ND license (http://creativecommons.org/licenses/by-nc-nd/4.0/). 


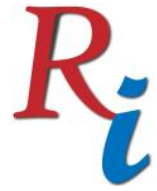

\section{Asia Proceedings of Social Sciences \\ (APSS) \\ www.readersinsight.net/APSS}

\section{A b s t r a c t}

This paper will review and discuss the presence of healthcare facilities in Melaka while it was under Portuguese rule from 1511 to-1641. The presence of healthcare facilities, while recorded, has not been studied in detail. While most of Portuguese Melaka was destroyed by the Dutch bombardment of 1641, some of the healthcare facilities that existed in the city were recorded even though they were eventually destroyed by the Dutch as they took over the city. This paper will record some of these institutions and detail the type of healthcare provided. Here, Portuguese records will be reviewed and evidence of hospitals will be elaborated upon. This paper will rely solely on historical writings by modern scholars and where possible, ancient Portuguese records. This paper aims to enable us to better understand the role of hospitals in the city of Melaka and why the Portuguese emphasized building them from an early period.

\section{Rese a r ch H i g h I igh t s}

The presence of hospitals in Melaka is highly connected to the fact that Melaka was a city that was constantly under siege from foreign powers and that there was always a constant supply of wounded soldiers that needed treatment from the scars of battle. Another factor is that the city was located close to a swamp and this may have caused a lot of people to fall sick since areas that are located close to swamps are generally unhygienic. Many Europeans would not have been used to tropical conditions. The surprising thing about Melaka is that it supported two hospitals, given the limited resources that the city had. There was a hospital for the poor and one for the Europeans. It appears here that the Portuguese paid a lot of attention to healthcare, indicating that there were various health problems faced by their community in the city.

\section{Research Objectives}

The objective of this research is to study the history and growth of healthcare facilities in the city of Melaka from 1511 to 1641 . In a city where most of the population were military men and travellers, it is not surprising that there was focus on healthcare. The Portuguese provided healthcare at all their fortresses in Asia (Macgregor, 1955). In between 1519 and 1520 there was only approximately 200 men of Portuguese descent in the city. The first hospital was founded in 1511 in order to treat the soldiers who had suffered in the war against the Melakan Sultanate (Cardon, 1934). At a later period, another hospital was established for the nonPortuguese population of the city. The hospitals were either connected to the Portuguese crown or to the church, and in one case, control of a hospital seems to have shifted from the crown to the state. This research is significant as it sheds light on colonial atitudes towards healthcare in the $16^{\text {th }}$ and $17^{\text {th }}$ century. It will also allow us to deepen our understanding about the various types of organizations that ran hospitals in the city. 


\section{Methodology}

Given that these hospitals were destroyed during the Dutch attack on the city in 1641, it is not possible to obtain records from any modern organization that might be able to shed light on its past. Source contemporary with the Portuguese period will be utilized to gain a better understanding about the condition of healthcare in the city at that time. The types of sources used can be divided into three parts. The first are Portuguese government sources, such as correspondence between people working in the city and their superiors in Portugal. The second type of source are letters between Christian missionary bodies and their superiors in Portugal, Spain and Rome. The third are traveller reports. Most travellers are from various nationalities such as Portuguese, Dutch, Spanish, English and French. Unfortunately, there are no local sources on Melaka during this period of its history. The first and second types of reports are more important since the government and church were both directly in charge of hospitals at the time. Traveller accounts only tell us about the location of the hospitals within the city.

\section{Results}

There were two hospitals in the city, one for the poor ( $O$ Hospital dos Pobres) and one for the rich (O Hospital Real), both within the city walls (Maxwell, 1911). The older of the two appears to be $O$ Hospital dos Pobres. O Hospital Real received as many as 500 patients per year. Patient care was good, although the quality of doctors was not according to a visitor, Pyrard de Laval (Cardon, 1934). Linschoten, another visitor remarked that the Portuguese of Melaka were struggling to live in a hotel climate and were constantly beset by health problems, some of which proved fatal. Many Christian missionaries including the St Francis Xavier himself, provided voluntary services when they could (Coleridge, 1872). In fact the Confraternity of Mercy, which was already running $O$ Hospital dos Pobres from an earlier time, took over the running of $O$ Hospital Real in the 1540s (Macgregor, 1955). This shows that the Portuguese government was already beginning to relinquish control of its hospitals by that period probably because they were too expensive to run and that there was sufficient charitable organizations to take over.

\section{Findings}

It seems that the growth of hospitals and then constant emphasis on them was caused by the fact that Melaka had an unhealthy climate to begin with, which was more important then the casualties caused by all the wars that Melaka was forced to engage in. Nonetheless, the earlier focus on hospitals was directly a government incentive for the soldiers to be treated by the state, which is why hospitals were provided at every fort. This was because in the initial stages 


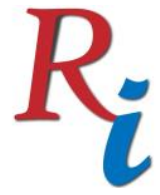

\section{Asia Proceedings of Social Sciences \\ (APSS) \\ www.readersinsight.net/APSS}

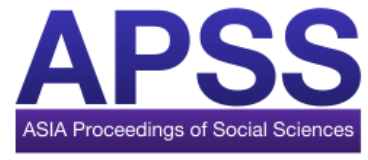

of its expansion, the Portuguese were fighting many wars and the health of their soldiers was paramount.

\section{References}

Cardon, R. (1934) "Portuguese Malacca" in Journal of the Malaysian Branch of the Royal Asiatic Society Vol. 12, No. 2 (119) (August, 1934), pp. 1-23.

Coleridge, H. J. (1872a) The Life and Letters of St Francis Xavier. Volume the First. London: Burns and Oates.

Macgregor, I. A. (1955) "Notes on the Portuguese in Malaya" in Journal of the Malaysian Branch of the Royal Asiatic Society Vol. 28, No. 2 (170) (May, 1955), pp. 4-47.

Maxwell, W. G. (1911) "Barretto de Resende's Account of Malacca" in Journal of the Straits Branch of the Royal Asiatic Society, No. 60 (December, 1911), pp. 1-24.

Author's Biography

Meljev Singh Sidhu was a former student of Universiti Sains Malaysia, completing his PhD in 2018. His dissertation studied the building materials of the Bujang Valley, a cluster of tradebased settlements located in the state of Kedah, Malaysia. His interests extends to the study of ancient Malay settlements throughout the Peninsular in the pre-Islamic period and also the architecture and constructions at other regional ports in Southeast and South Asia. He also studies various facets of Malaysia's colonial past. He is currently applying for a postdoctorate in history and hopes to secure a position as a full-time researcher. 